\title{
Role of gallstones in typhoid carriage in Egyptian patients
}

\author{
Marwa A. Mansour ${ }^{1}$, Tarik I. Zaher ${ }^{2}$, Amany M. Ibrahim³, Amira S. Ahmed ${ }^{3}$, Islam M. Ibrahim4 ${ }^{4}$ Ashraf Goda4, \\ Nehad F. Ahmed ${ }^{5}$ \\ ${ }^{1}$ Medical Microbiology and Immunology Department, Faculty of Medicine, Zagazig University, Egypt \\ ${ }^{2}$ Tropical Medicine Department, Faculty of Medicine, Zagazig University, Egypt \\ ${ }^{3}$ Internal Medicine Department, Faculty of Medicine, Zagazig University, Egypt \\ ${ }^{4}$ General Surgery Department, Faculty of Medicine, Zagazig University, Egypt \\ ${ }^{5}$ Histology Department, Faculty of Medicine, Zagazig University, Egypt
}

\begin{abstract}
Objectives: Salmonella typhi forms biofilm on the surface of gallstones promoting colonization and carrier state. The aims are to detect its frequency in chronic calcular cholecystitis patients, to find out their antibiotic resistance pattern, and also to examine biofilm on the surface of gallstones and detect its correlation to antibiotic susceptibility pattern.
\end{abstract}

Materials and methods: The study group included 257 patients with chronic calcular cholecystitis. S. typhi was isolated from gall bladder specimens. Antibiotics susceptibility tests of the isolates were done. Biofilm on surface of gallstones were visualized using scanning electron microscopy. Virulence (Vi) antibodies against S. typhi were studied in sera of 257 healthy controls.

Results: $10.9 \%$ of patients were chronic typhoid carriers compared to only $3.5 \%$ of the controls $(O R=3.37, p=0.002)$. Multidrug resistance was detected in $35.7 \%$ of isolates. S. typhi biofilms on the surface of the $21 / 28$ (75\%) gallstones were detected. Ninety percent of the strains that produced maximum amount of biofilm were multidrug-resistant.

Conclusion: Chronic calcular cholecystitis patients are more prone to typhoid carriage due to biofilm formation of $S$. typhi on the surface of gallstones. J Microbiol Infect Dis 2012; 2(4): 142-149

Key words: Gall bladder, Chronic calcular cholecystitis, Salmonella typhi, biofilm, antibiotic resistance

\section{Mısırlı hastalarda tifo taşıyıcılığında safra taşlarının rolü}

\section{ÖZET}

Amaç: Salmonella typhi safra taşlarının üzerinde biyofilm oluşturarak kolonizasyonu ve taşıyıcılığı kolaylaştırır. Bu çalışmanın amacı, kronik taşlı kolesistiti olan hastalarda sıklığını saptamak, antibiyotik direnç paternlerini belirlemek, ayrıca safra taşları üzerindeki biyofilmi incelemek ve antibiyotik duyarlılık paterni ile ilişkisini araştırmaktır.

Gereç ve yöntem: Çalışmaya kronik taşlı kolesistiti olan 257 hasta alındı. S. typhi safra kesesi örneklerinden izole edildi. İzolatların antibiyotik duyarlılıkları çalışıldı. Safra taşları üzerindeki biyofilm, tarama electron mikroskobu ile gözlendi. S. typhi'ye karşı virulans (Vi) antikorları, 257 sağlıklı kontrolde çalışıldı.

Bulgular: Hastaların \%10,9'u, kontrollerin ise \%3, $5^{\prime}$ i of kronik tifo taşıyıcısı idi (OR=3,37, $\left.p=0,002\right)$. Çoklu ilaca direnç, izolatların \%35,7'sinde saptandı. S. typhi biyofilmi, 28 safra taşının 21'inde (\%75) saptandı. Aşırı miktarda biyofilm üreten kökenlerin \%90'ı, çoklu ilaca dirençli idi.

Sonuç: Kronik taşlı kolesistiti olan hastalar, S. typhi'nin safra taşı üzerinde biyofilm yapmasına bağlı olarak tifo taşıyıcılığına eğilimlidirler.

Anahtar kelimeler: Safra kesesi, kronik taşlı kolesistit, Salmonella typhi, biyofilm, antibiyotik direnci

Correspondence: Marwa Abd El-Azim Mansour, Medical Microbiology and Immunology Department,

Faculty of Medicine, Zagazig University, Fakous, Sharkia, Egypt. Fax: +20 553981289 Email: marwa_abdelazimm@yahoo.com Received: 07 August, 2012 Accepted: 10 November, 2012

Copyright (C) Journal of Microbiology and Infectious Diseases 2012, All rights reserved 


\section{INTRODUCTION}

Typhoid fever is an important health problem in many developing countries. ${ }^{1}$ Salmonella typhi causes an estimated 21 million new cases of typhoid fever and 216,000 deaths worldwide every year. $^{2}$ Egypt remains a country with intermediate incidence of one to 100 per 100,000 cases of typhoid fever, below nations such as India and Indonesia. $^{3}$

In general, $2-5 \%$ of all individuals who develop clinical or subclinical infection with $S$. typhi become chronic gall bladder carriers and thereby serves to maintain endemicity of the disease. ${ }^{4}$

Development of chronic typhoid carriage is frequently associated with the presence of gall bladder abnormalities especially gallstones. ${ }^{5}$ About $10 \%$ of patients with cholelithiasis and $30 \%$ of gallbladder carcinoma in endemic areas are chronic typhoid carriers. ${ }^{6-8}$ Gall stones arise from the precipitation of cholesterol and calcium salts in super-saturated bile. They are classified by their content of cholesterol as either cholesterol, pigmented or mixed gallstones. ${ }^{9}$

Recent evidence indicates that $S$. typhi forms biofilms on the surface of cholesterol gallstones. Biofilms are communities of microorganisms that adhere to each other and to inert or live substrates and are encased in an extracellular matrix. ${ }^{10}$ Biofilm formation is dependent on the presence of bile because organisms cultured without bile do not readily form biofilm. ${ }^{11,12}$

Planktonic cells from this sessile, matrixbound population are continuously shed, which can result in systemic infection or release of the organism into the environment. Bacteria shed by asymptomatic carriers contaminate food and water and account for much of the person-to-person transmission of $S$. typhi in underdeveloped countries. ${ }^{13}$ One of the most important properties of the biofilm-associated bacteria in clinical medicine is the markedly enhanced resistance to antimicrobial agents, through protection by the extracellular polymeric substance (EPS), leading to multidrug resistance and therapeutic failure. ${ }^{14}$

Cholecystectomy increases the cure rate, but it does not guarantee elimination of the carrier state because additional foci of infection can persist in the biliary tree, mesenteric lymph nodes or liver. Hence, the most effective treatment is a combination of surgery and antibiotics. ${ }^{15}$ The aim of this work is to detect the frequency of $S$. typhi in Egyptian calcular cholecystitis patients, to find out the antibiotic resistance pattern of isolates, and also to examine biofilm formation on the surface of the gallstones and detect its possible correlation to antibiotic susceptibility pattern.

\section{Research question}

Does patient with gallstones is more prone to chronic typhoid carriage?

\section{Research hypothesis}

Patients with chronic calcular cholecystitis are more prone to typhoid carriage due to biofilm formation of $S$. typhi on the surface of gallstones.

\section{Objectives}

1. To compare the frequency of chronic typhoid carriage in patients complained of chronic calcular cholecystitis versus healthy controls.

2. To assess antibiotic resistance pattern of $S$. typhi isolates.

3. To ascertain the presence of biofilm on surface of the gallstones.

4. To detect possible correlation between biofilm grading and antibiotic susceptibility pattern.

\section{MATERIALS AND METHODS}

The present study was carried out in Fakous and Minia El-Kamh, Sharkia Governorate, Egypt during the period from February 2009 to March 2012. Fakous and Minia El-Kamh are rural districts with about 500,000 and 600,000 populations; respectively.

Study design: Case-control study.

\section{Sample size determination}

Up to our knowledge, this study was the first one to discuss this topic in Middle-East countries. Hence, we depend on other developing countries with nearly the same predisposing factors like that of Egypt. 257 of each arm using the following equation. ${ }^{16}$

$$
n=\frac{K\left[\left(P 1(1-P 1)+P 2\left(1-P_{2}\right)\right.\right.}{(P 1-P 2)^{2}}
$$

$\mathrm{K}=10.5$ assuming significance of $5 \%$ and power of $90 \%$. 
$\mathrm{P} 1=0.1$ as about $10 \%$ of patients with gallstones in endemic areas are typhoid carriers (known from previous studies).

P2 $=0.03$ as about $3 \%$ of general population in endemic areas are typhoid carriers (known from previous studies).

Ethical considerations: The study was reviewed and approved by the review boards of the participating institutes and informed consent was obtained from all participants.

This study was conducted in health insurance, general or private hospitals in Fakous and Minia El-kamh. It included two groups; the study group included patients presented by chronic cholecystitis (178/257) and acute on chronic cholecystitis (79/257). Patients were subjected to either laparoscopic (201 patients) or open cholecystectomy (56 patients; 40 of which were acute on chronic cholecystitis patients). Admission to hospital 24 hours before operation for preoperative assessment and investigations was provided. No antibiotics were prescribed before surgery while third generation cephalosporins were given intra-operatively. The healthy control group included individuals presented without calcular cholecystitis or acute fever.

Due to expected low prevalence of typhoid carriage; the gall bladder specimens from cases as well as serum samples from controls were taken from those with past history suggestive of typhoid fever; fever associated with headache, abdominal discomfort, weight loss, cough, anorexia, vomiting or constipation. ${ }^{17}$

Sample collection: Gallbladder tissues, gallstone sections (Figure 1) and bile obtained from each patient after cholecystectomy were used for cultivation and immediate freezing at $-20^{\circ} \mathrm{C}$ for DNA extraction. Blood samples from healthy controls were centrifuged, and sera were stored at $-20^{\circ} \mathrm{C}$.

Isolation and identification of S. typhi: Gallbladder tissue and gallstone sections were injected into a Stewart transport medium (Oxoid, Basingstoke, UK). One gram of gallbladder tissue was crushed in a sterile mortar and pestle in one $\mathrm{ml}$ saline and the tissue homogenate was used for culture. Gallstones were washed with water, dried and grinded to a fine powder with a mortar and pestle. They were homogenized in a $50 \mathrm{~mL}$ conical tube containing $1 \mathrm{ml}$ of 1 x PBS. A portion of tissue and a loopfull of gallstone homogenate were cultured on selenite $\mathrm{F}$ medium (Oxoid, Basingstoke, UK) and after 12 to 24 hours incubation in $37^{\circ} \mathrm{C}$, it was subcultured on selective Salmonella-Shigella agar (SS) medium (Oxoid, Basingstoke, UK) and incubated for 24 hours at $37^{\circ} \mathrm{C}$. On the other hand, approximately $1 \mathrm{~mL}$ of bile was obtained, homogenized and plated. ${ }^{18}$

If growth was present, individual colonies were identified by colonial morphology, Gram staining and biochemical testing; triple sugar iron test, IMViC (Indole, Methyl Red, Voges' Proskauer, Citrate utilization) tests, motility and urease and lysine decarboxylase activities detection. ${ }^{19}$

Serotyping was performed using somatic, flagellar and virulence (Vi) Salmonella antisera (Difco, Detroit, Michigan) to determine corresponding antigens of $S$. typhi by the slide agglutination method according to the manufacturer's instructions.

Antimicrobial susceptibility testing: It was determined by the disc diffusion method and interpreted according to the Clinical and Laboratory Standards Institute (CLSI) criteria (CLSI, 2008). ${ }^{20}$ The following antimicrobial agents (Oxoid, Basingstoke, UK) were tested: ampicillin $(10 \mu \mathrm{g})$, chloramphenicol $(30 \mu \mathrm{g})$, co-trimoxazole $(25 \mu \mathrm{g})$, ciprofloxacin $(5 \mu \mathrm{g})$ and ceftriaxone $(30 \mu \mathrm{g})$. $S$. typhi isolate was classified as multidrug resistant (MDR), if it was resistant to all three first-line antibiotics used to treat typhoid fever: ampicillin, chloramphenicol, and co-trimoxazole. ${ }^{21}$

Molecular studies: To confirm the identification of S. typhi, nested PCR was done for genomic DNA from culture positive samples, as well as gallbladder tissue, gallstone and bile samples.

DNA extraction was done using QIAamp DNA mini kit (Qiagen $\mathrm{GmbH}$, Hilden, Germany) according to the manufacturer's instructions. The extracts were then kept at $-20^{\circ} \mathrm{C}$ until they were used in PCR reactions. The nested PCR described by Song and others ${ }^{22}$ with a modified forward primer for the first PCR as suggested by Frankel and co-workers ${ }^{23}$ to increase its specificity. It is based on the amplification of unique sequences in the VI region of the flagellin gene. The first reaction amplified a 458-basepair (bp) fragment corresponding to nucleotides 1063-1530 of the gene and a nested 343-bp fragment corresponding to nucleotides $1072-1435$ was amplified in the second reaction. 
The oligonucleotide primers (Sigma-Aldrich Chemie, Munich, Germany) for the first round of PCR were forward - ST 1 5'- ACT GCT AAA ACC ACT ACT-3' and reverse - ST2 5'- TTA ACG CAG TAA AGA GAG-3'. For the nested PCR, these were forward- ST3 5'- AGA TGG TAC TGG CGT TGC TC-3' and reverse -ST4 5'- TGG AGA CTT CGG TCG CGT AG-3' primers. A PCR reaction using PCR-gold master-mix beads (Bioron, Germany); contain (2.5U taq DNA polymerase, $250 \mathrm{mM}$ each dNTP, $10 \mathrm{mM}$ tris $\mathrm{Hcl}(\mathrm{pH} \mathrm{9.0)}$, $30 \mathrm{mM} \mathrm{kcl}, 1.5 \mathrm{mM} \mathrm{Mgcl} 2$ ) to which $70 \mathrm{ng}$ template DNA, 20 pmole for each primer and distilled water was added to a total volume $50 \mu$ l. They were mixed well by vortexing. The reaction was performed in thermal cycler (Biometra, Goettingen, Germany) under the following conditions: 40 cycles for 1 min denaturation at $94^{\circ} \mathrm{C}, 1 \mathrm{~min} 15 \mathrm{~s}$ annealing at $57^{\circ} \mathrm{C}$, and $1 \mathrm{~min}$ elongation at $72^{\circ} \mathrm{C}$, with a final elongation step extended to $7 \mathrm{~min}$. The nested PCR master mix was the same as that of the first-round PCR, except it contained 21 pmol of each primer ST3 and ST4 and $4 \mu \mathrm{l}$ of DNA template (1:6-diluted product of the primary cycle). Thermal cycling was carried out as described for first-round PCR, except that the annealing temperature was set to $63^{\circ} \mathrm{C}$. Each run of PCR amplification included both positive and negative controls where the positive control included DNA extracted from S. typhi (National research center, Cairo, Egypt) while the negative control included no template DNA to avoid false positive results caused by suspected contamination. The amplified DNA was separated by $2 \%$ agarose gel electrophoresis, stained with ethidium bromide, and visualized by UV transillumination.

Scanning Electron Microscopy (SEM): SEM processing and examination were carried out in the Anatomy Department, Faculty of Medicine, Ain Shams University, Egypt. Gallstones recovered from positive and negative patients for $S$. typhi were rinsed with sterile sodium phosphate buffer, fixed in $2 \%$ glutaraldehyde, and air dried in a Laminar flow hood. The specimens were dehydrated in ascending grades of ethanol, dried with a Baltec 030 critical point dryer (Natick, Massachusetts, USA) and coated with gold using Baltec 030 sputter coater. Examination was carried out using Philips XL30 SEM (Amsterdam, Nether- lands) under a high tension of $25 \mathrm{kV}$. According to Crawford et al., ${ }^{24}$ biofilms on gallbladder stone surfaces were graded quantitatively. They were graded as ++: biofilm cover an estimated $80-95 \%$ of gallstone surface, + : little biofilm present (covering $\approx 5-20 \%$ of gallstone surface), -: absence of biofilm on gallstone surface.

Seropositivity: Virulence (Vi) antibodies were measured using ELISA (VaccZyme ${ }^{\mathrm{TM}}$ Binding Site Group Ltd, Birmingham, UK) to detect chronic typhoid carriage in the control group according to the manufacturer's instructions.

\section{Statistical analysis}

Data was checked, entered and analyzed using SPSS version 15 for data processing and statistic. Data was expressed as number and percentage for qualitative variables and mean \pm standard deviation for quantitative one. $P$ value of $<0.05$ indicates significant results. Odds ratio and $95 \%$ confidence interval $(\mathrm{Cl})$ were calculated.

\section{RESULTS}

Demographic, clinical and laboratory data of calcular cholecystitis patients are given in Table 1. Patients included 155 females and 102 males with mean age of $42.17 \pm 13.47$ years (range 20 66 years). The controls included 140 females and 117 males with mean age of $40.22 \pm 13.11$ years (range 20-63 years).

Twenty-eight out of 257 (10.9\%) patients were chronic typhoid carriers compared to only $9 / 257(3.5 \%)$ of the controls (Odds ratio=3.37, $95 \%$ Confidence Interval $=1.56-7.29, \mathrm{P}=0.002$ ). Hence, the total percentage of typhoid carriage in both groups was 37/514 (7.2\%). Twenty-eight, 12 and $4 \mathrm{~S}$. typhi isolates were from gallstones, gall bladder epithelial tissues and bile; respectively. Nested PCR amplification products of S. typhi isolates are demonstrated in Figure 2. Varying percentages of antibiotic resistance patterns of isolates were observed (Table 2).

S. typhi biofilm on the surface of the $21 / 28$ $(75 \%)$ gallstones were detected. Correlation between biofilm grading and antibiotic susceptibility pattern was presented in Figure 3. 
Table 1. Demographic and clinical data of calcular cholecystitis patients.

\begin{tabular}{ll}
\hline Demographic data & Calcular cholecystitis patients No. (\%) \\
\hline Age (years) & \\
$20-40$ & $92(35.8 \%)$ \\
$40-60$ & $135(52.5 \%)$ \\
$>60$ & $30(11.7)$ \\
Sex & \\
$\quad$ Male & $102(39.7 \%)$ \\
$\quad$ Female & $155(60.3 \%)$ \\
Clinical data & \\
BMl ( $\geq 25 \%)$ & $171(66.5 \%)$ \\
Dyspepsia & $240(93.4 \%)$ \\
\hline
\end{tabular}

Table 2. The percentage of antibiotic resistance pattern of isolates

\begin{tabular}{ll}
\hline Antibiotics & Resistance $\mathrm{n}(\%)$ \\
\hline Ampicillin & $13(46.4)$ \\
Chloramphenicol & $12(42.9)$ \\
Co-trimoxazole & $11(39.2)$ \\
Ciprofloxacin & $1(3.6)$ \\
Ceftriaxone & $1(3.6)$ \\
SDR & $14(50.0)$ \\
MDR & $10(35.7)$ \\
\hline
\end{tabular}
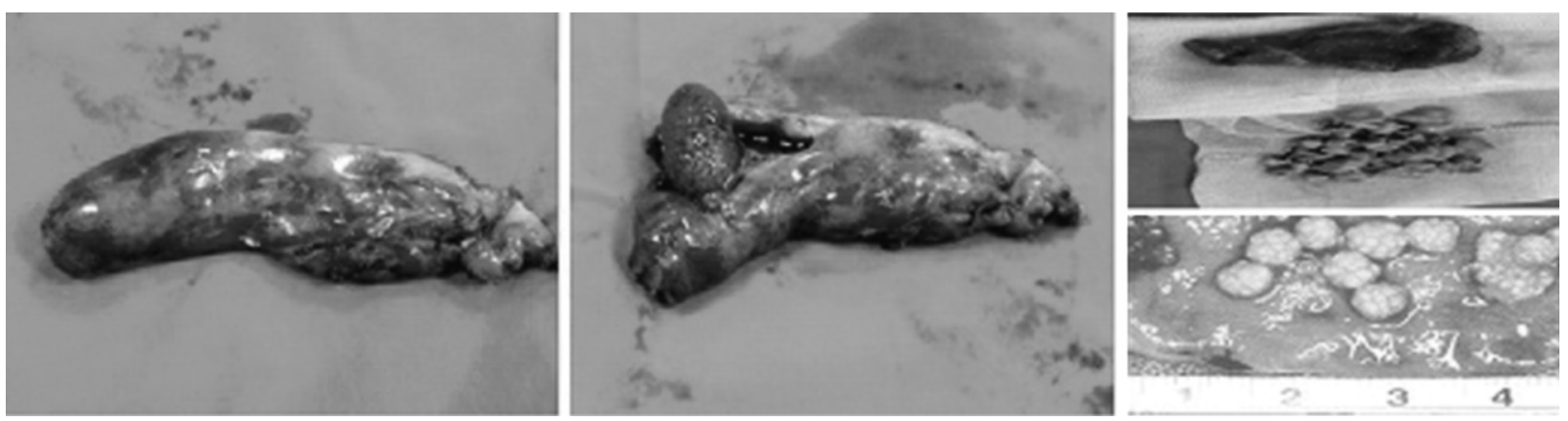

Figure 1. Chronic calcular cholecystitis affected gallbladder and gallstones

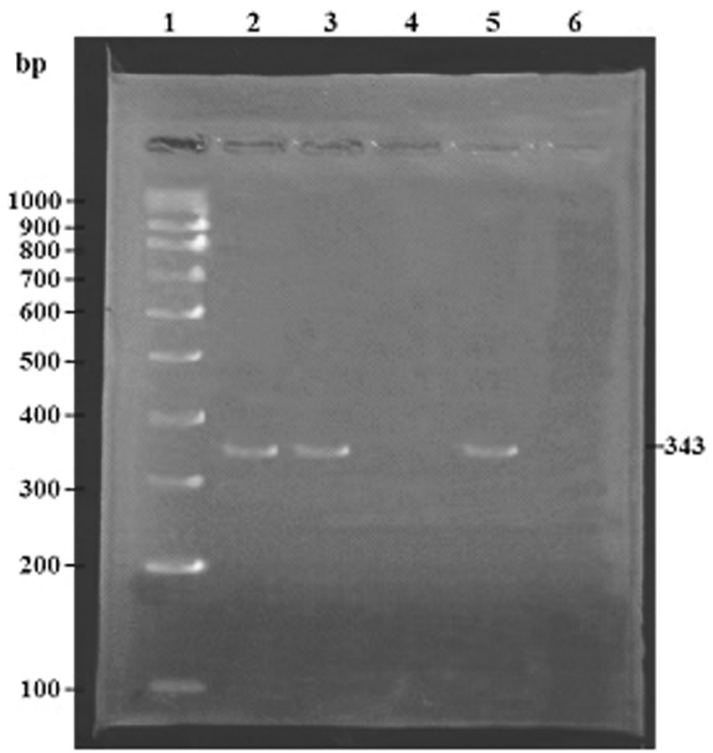

Figure 2. Ethidium bromide stained agarose gel showing results of nested PCR technique for detection of the flagellin gene of S. typhi; Lane 1: Molecular weight marker (100-1000bp), lanes 2, 3: Amplification products of $343 \mathrm{bp}$ from the nested PCR, lane 4: No band, lane 5: Positive control, and lane 6: Negative control 


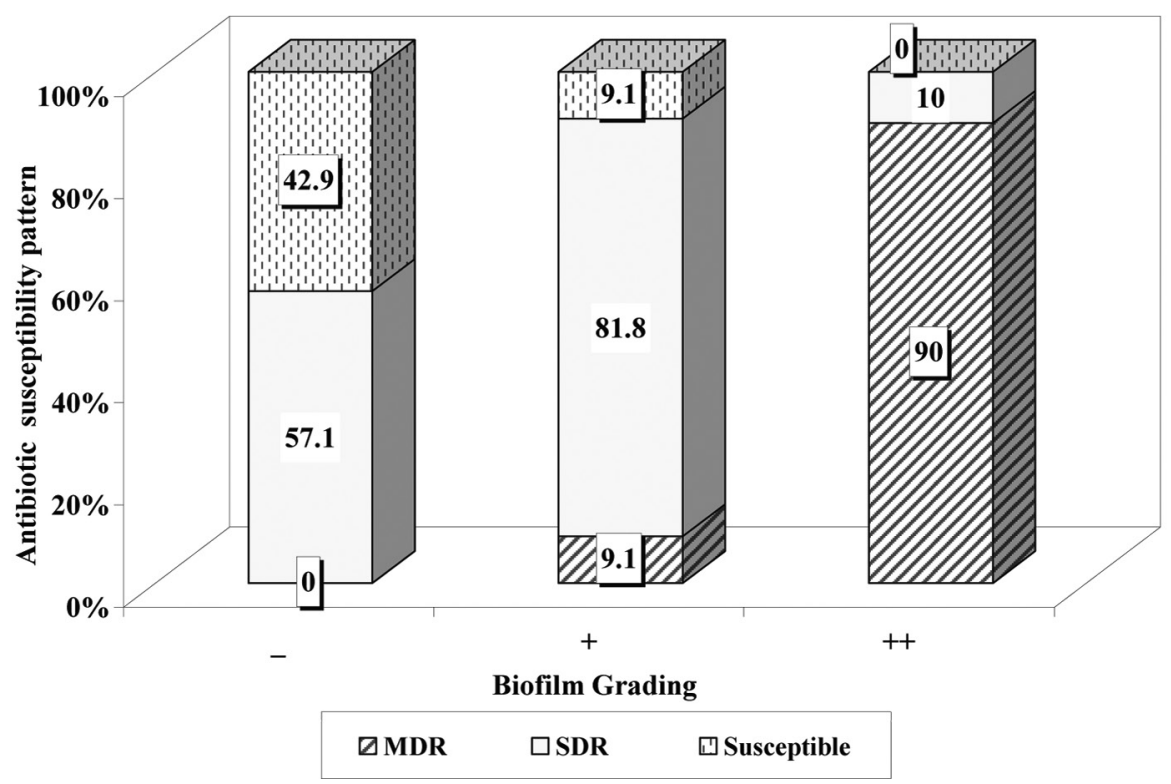

Figure 3. Correlation between biofilm grading and antibiotic susceptibility pattern

\section{DISCUSSION}

Individuals with gallstones are more likely to become typhoid carriers in whom antibiotic treatment is often ineffective. ${ }^{25}$ In this study, we tried to find the role of gallstones in typhoid carriage in Egypt that has intermediate incidence of typhoid.

In this study, the patients' ages ranged from 20-66 years and the peak incidence was in the fourth decades of life. This finding is in agreement with the statement that chronic cholecystitis is common among the age of forty. ${ }^{18,26}$ In addition, the high incidence of females $(60.3 \%)$ affected by chronic cholecystitis is attributed to estrogens which tend to make hepatic bile more lithogenic. ${ }^{27}$

The current study showed that $66.5 \%$ of our patients were obese. This was in accordance with Montasser and El-Sayed who detected this in $70 \%$ of their patients. They explained this by increased cholesterol synthesis that predisposes to cholesterol cholelithiasis. ${ }^{17}$

For detection of chronic typhoid carriage, we used conventional methods of identification confirmed by nested PCR for DNA from culture positive isolates as well as gallbladder samples from patients and $\mathrm{Vi}$ antibodies in sera of controls. This choice was in accordance to Nath et al. ${ }^{27}$ who found that for detection of typhoid carriers, $\mathrm{Vi}$ antibodies in serum are comparable to PCR in biliary specimens as no significant difference between $S$. typhi DNA extracted from hepatobiliary specimens from 424 autopsies free from gall bladder pathology on postmortem examination and Vi antibodies in 508 healthy volunteers.

In this study, $10.9 \%$ of patients with chronic calcular cholecystitis were typhoid carriers compared to only $3.6 \%$ of the controls with a total percentage of typhoid carriers of $7.2 \%$ in both groups. Twenty-eight, 12 and 4 gallstones, gall bladder epithelial tissues and bile samples; respectively were positive for S. typhi.

This frequency was higher than that of Crawford et al. ${ }^{28}$ who investigated this condition in typhoid endemic Mexico City. They reported the presence of S. typhi in five of the 103 patients with cholelithiasis ( $5 \%$ of patient samples). Five, two and one gallstones, gall bladder epithelial tissues and bile; respectively were positive for $S$. typhi.

Moreover, Vaishnavi and co-workers found that $6.9 \%$ of patients with gall bladder/common bile duct stones compared to $3.9 \%$ of patients with miscellaneous gastrointestinal disorders had Salmonellae in their bile samples after bacteriological investigations. ${ }^{24}$ The high prevalence of typhoid fever in Egypt may explain this difference. In addition, it may be as a result of our selection of the studied groups with past history suggestive of typhoid fever due to the expected low prevalence of typhoid carriage.

On the contrary, Montasser and El-Sayed found that bile and gall bladder tissue cultures gave negative results for Salmonella in fifty Egyp- 
tian cases with chronic cholecystitis subjected to cholecystectomy ${ }^{17}$. This may be explained by our use of the more sensitive method; nested PCR for detection of S. typhi. ${ }^{29}$ Also, there was a low prevalence; $4 / 977(0.41 \%)$ of chronic typhoid infection in case-control study in Shanghai, China. ${ }^{30}$

The highest antibiotic resistance was to ampicillin (46.4\%), chloramphenicol $(42.9 \%)$ and co-trimoxazole $(39.2 \%)$ which are conventionally used to treat typhoid fever and least resistant to ciprofloxacin (3.6\%) and ceftriaxone (3.6\%). Similar results where some isolates showed the resistances to these antibiotics were reported. 14,31,32

Fluoroquinolones (ciprofloxacin) and broad spectrum cephalosporin (cefotaxime) are the most commonly used antimicrobial agents for the treatment of invasive Salmonella infections in man. However, treatment failures due to invasive strains of Salmonella displaying reduced susceptibility have been reported where resistance to ciprofloxacin was found in $<2 \% .{ }^{33}$ In this study out of various $S$. typhi isolates, $35.7 \%$ were multidrug resistant and $50.0 \%$ were single drug resistant. This was higher than Bhattacharya and others ${ }^{34}$ who reported that MDR was found in $12.75 \%$ of isolates. However, it was lower than that was reported by Raza et al. 16/30 (53.33\%). ${ }^{35}$

Twenty-one out of 28 (75\%) gall bladder typhoid carrier patients in our study had S. typhi on the surface of gallstones. This was in agreement with Prouty et al. who demonstrated that Salmonella can form biofilms on human gallstones in vitro and that biofilm formation is markedly enhanced in the presence of bile. ${ }^{12}$ Also, Crawford et al. ${ }^{28}$ performed SEM for S. typhi biofilm on the surface of the gallstones revealed that gallstones from three out of four of these patients exhibited a dense bacterial biofilm. The gallstone from the patient who lacked biofilm formation was thought to be a pigment stone, with calcium bilirubinate and not cholesterol as the main constituent.

In this current study, $90 \%$ of the strains that produced maximum amount of biofilm were MDR. This in accordance with that of Raza et al. ${ }^{35}$ who detected that in $81.82 \%$ of MDR isolates.

Conclusion: These data correlate with previous in vivo observations and support the hypothesis that chronic carriage of $S$. typhi is mediated by biofilm formation on gallstones. In addition, they demonstrate the presence of a subset of healthy carriers in an endemic population and highlight the importance of the development of methods to identify and successfully treat such patients.

Investigation of cholesterol biofilm inhibitors could lead to the development of promising therapies to eliminate typhoid carriage, especially in areas of high endemicity. In addition, meticulous use of antibiotic may contribute to the efforts of limiting the spread of MDR isolates.

\section{REFERENCES}

1. Hatta M, Smits H. Detection of Salmonella typhi by nested polymerase chain reaction in blood, urine and stool samples. Am J Trop Med Hyg 2007; 76:139-143.

2. Zhou L, Pollard A. A fast and highly sensitive blood culture PCR method for clinical detection of Salmonella enterica serovar typhi. Ann Clin Microbiol Antimicrob 2010; 9:14.

3. Ghenghesh KS, Franka E, Tawil K, et al. Enteric fever in Mediterranean North Africa. J Infect Dev Ctries 2009; 3:753-761.

4. Levine MM, Black RE, Lanata C, Chilean Typhoid committee. Precise estimation of the numbers of chronic carriers of Salmonella typhi in Santiago, Chile, an endemic area. J Infect Dis 1982;146: 724-726.

5. Lai CW, Chan RC, Cheng AF, Sung JY, Leung JW. Common bile duct stones: A cause of chronic salmonellosis. Am J Gastroenterol 1992; 87:1198-1199.

6. Sharma V, Chauhan VS, Nath G, Kumar A, Shukla VK. Role of bile bacteria in gallbladder carcinoma. Hepatogastroenterology 2007;54:1622-1625.

7. Vaishnavi C, Kochar R, Singh G, Kumar S, Singh S, Singh K. Epidemiology of typhoid carriers among blood donors and patients with biliary, gastrointestinal and other related diseases. Microbiol Immunol 2005; 49: 107-112.

8. Shukla VK, Singh H, Pandey M, Upadhyay SK, Nath G. Carcinoma of the gallbladder is it a sequel of typhoid? Dig Dis Sci 2000; 45:900-903.

9. Elwood D. Cholecystitis. Surg Clin North Am 2008; 88:12411252.

10. Monds RD, O'Toole GA. The developmental model of microbial biofilms: ten years of a paradigm up for review. Trends Microbiol 2009; 17:73-87.

11. Maurer KJ, Carey MC, Fox JG. Roles of infection, inflammation, and the immune system in cholesterol gallstone formation. Gastroenterology 2009; 136:425-440.

12. Prouty AM, Schwesinger WH, Gunn JS. Biofilm formation and interaction with the surfaces of gallstones by Salmonella spp. Infect Immun 2002; 70:2640-2649.

13. Crawford W, Gibson DL, Kay WW, Gunn, JS. Identification of a bile-induced exopolysaccharide required for Salmonella biofilm formation on gallstone surfaces. Infect Immun 2008; 76:5341-5349.

14. Papavasileiou K, Papavasileiou E, Tseleni-Kotsovili A, et al. Comparative antimicrobial susceptibility of biofilm versus planktonic forms of Salmonella enterica strains isolated from children with gastroenteritis. Eur J Clin Microbiol Infect Dis 2010;29:1401-1405.

15. Nath G, Singh YK, Maurya P, Gulati AK, Srivastava RC, Tripathi SK. Does Salmonella typhi primarily reside in the liver of chronic typhoid carriers? J Infect Dev Ctries 2010; 4: 259-261.

16. Paecock JL, Paecock PJ. Oxford handbook of medical statistics. Oxford University Press 2011. 
17. Montasser M, El-Sayed MK. Chronic salmonellosis in cases of chronic cholecystitis subjected to cholecystectomy. Sci Med J Cai Med Synd 1990; 2:17-25.

18. Eslami G, Nowruzi J, Fllah F, et al. Detection of bacteria responsible for gallbladder inflammation and gallstones. Iranian J Clin Infect Dis 2007; 2:139-141.

19. Forbes B, Sahm D and Weissfeld J. Overview of bacterial identification, methods and strategies. In: Baily and Scott's Diagnostic Microbiology. Belly A and Forbes B (eds). 12th ed. Mosby, New York; 2007:221-245.

20. Clinical and Laboratory Standards Institute. Performance standards for antimicrobial susceptibility testing. Document M100-S18, Wayne, PA19087 USA, 2008.

21. Srikantiah P, Girgis FY, Luby SP, et al. Population-based surveillance of typhoid fever in Egypt. Am J Trop Med Hyg 2006; 74:114-119.

22. Song JH, Cho H, Park MY, et al. Detection of Salmonella typhi in the blood of patients with typhoid fever by polymerase chain reaction. J Clin Microbiol 1993; 31:1439-1443.

23. Frankel G, Newton SM, Schoolnik GK, Stocker BA. Unique sequences in the region VI of the flagellin gene of Salmonella typhi. Mol Microbiol 1989; 13:1379-1383.

24. Crawford RW, Rosales-Reyes R, Ramírez-Aguilar M et al. Gallstones play a significant role in Salmonella spp. gallbladder colonization and carriage. Proc Natl Acad Sci USA 2010; 107:4353-4358.

25. Vaishnavi C, Singh S, Kochhar R, Bhasin D, Singh G, Singh K. Prevalence of Salmonella enterica serover typhi in bile and stool of patients with biliary diseases and those requiring biliary drainage for other purposes. Jpn J Infect Dis 2005; 58:363-365.
26. Al-Sulaimaini SH, Alam MK, Sangupta H, et al. Incidence of cholelithiasis in patients attending King Abdul Aziz University Hospital. Saudi Med J 1986; 7:261-265.

27. Bell GD. Gallstones. Medical Education International Ltd. P. 1982:694-699.

28. Nath G, Maurya P, Gulati AK, et al. Comparison of Vi serology and nested PCR in diagnosis of chronic typhoid carriers in two different study populations in typhoid endemic area of India. Southeast Asian J Trop Med Public Health 2010; 41:636-640.

29. Prakash P, Mishra OP, Singh AK. Evaluation of nested PCR in diagnosis of typhoid fever. J Clin Microbiol 2005; 43: 431432.

30. Safaeian M, Gao Y, Sakoda L, et al. Chronic typhoid infection and the risk of biliary tract cancer and stones in Shanghai, China. Infect Agent Cancer 2011; 6:6.

31. Mirza SH, Hart CA. Plasmid encoded multi drug resistance in Salmonella typhi from Pakistan. Ann Trop Med Parasitol 1993; 87:373-377.

32. Senthilkumar B, Prabakaran G. Multidrug resistant Salmonella typhi in asymptomatic typhoid carriers among food handlers in Namakkal District, Tamil Nadu. Indian J Med Microbiol 2005; 23:92-94.

33. Whichard JM, Kathryn G, Stevenson JE, et al. Human Salmonella and concurrent decreased susceptibility to quinoIones and extended-spectrum cephalosporins. Emerg Infect Dis 2007; 13:1681-1688.

34. Bhattacharya SS, Das U, Choudhury BK. Occurrence \& antibiogram of Salmonella typhi \& S. paratyphi A isolated from Rourkela, Orissa. Indian J Med Res 2011; 133: 431-433.

35. Raza A, Haque A, Khurshid S, et al. In vitro relationship between differing levels of virulence and antibiotic resistance in Salmonella typhi. Int J Agri Biol 2003; 5:566-570. 